\title{
An empirical chromite classification for positive identification of kimberlite in diamond exploration
}

\author{
Steven Creighton and Thomas Stachel \\ Department of Earth and Atmospheric Sciences, University of Alberta, Canada
}

\begin{abstract}
Introduction
Chromium-bearing spinel (herein called chromite) is a robust mineral that is not readily affected by chemical weathering. It precipitates as a primary phase in kimberlites (and a range of other igneous rocks), has a large stability field - extending as deep as $200 \mathrm{~km}$ - in depleted cratonic peridotites, and occurs as inclusion in diamonds. Previous attempts to assign primary chromite paragenesis were based on chemical criteria derived from the statistical analysis of combined major and trace element analyses (Griffin et al. 1994; Fipke et al. 1995; Griffin and Ryan 1995; Griffin et al. 1997) or employed chromite morphology (Lee et al. 2003). Thus far, however, the utility of chromite in kimberlite and diamond exploration has been limited by a commonality of spinel compositions from a diversity of mafic and ultramafic rocks. To fully realize the potential of chromite as a first class exploration tool we are defining here simple compositional fields that allow for reliable source identification. By focusing on major elements only, we aim to provide a simple classification scheme that can be applied to large datasets without relying on cost-intensive trace element analyses.
\end{abstract}

\section{Database and classification}

We used the large (>26 000 analyses) database of Barnes and Roeder (2001) as the primary source of spinel compositional data. From this database we rejected analyses with analytical totals (based on all $\mathrm{Fe}$ expressed as $\mathrm{FeO}$ ) less than $90 \%$ and greater than $103 \%$. The remaining data were then filtered by paragenesis to give a database of 6058 spinel analyses from mafic and ultramafic bulk rock compositions. To this database we added an additional 2409 published and unpublished analyses: 824 chromites included in diamonds worldwide, 262 chromite analyses from spinel peridotite xenoliths, and 1322 analyses of Group 1 kimberlite groundmass spinels. From this combined database of 8466 spinel analyses we have identified four fields that can be used to distinguish chromites as (i) inclusions in diamonds / diamond indicators, (ii) ultramafic, (iii) mafic or "basaltic", and (iv) kimberlitic.

As already observed by Fipke et al. (1995), chromites included in diamonds have a restricted range of high
$\mathrm{Cr}_{2} \mathrm{O}_{3}$ concentrations and are magnesian in composition. From the diamond inclusion chromite compositions in our database, we have updated the compositional field of Fipke et al. (1995) to include chromites with $10-17 \mathrm{wt} \% \mathrm{MgO}$ and $60-70 \mathrm{wt} \% \mathrm{Cr}_{2} \mathrm{O}_{3}$. These compositional parameters describe $97 \%$ of diamond inclusion chromites in our database and form the basis for a classification as highly diamond favourable chromites (Figure 1). The robustness of the diamond inclusion (DI) chromite classification is demonstrated by the low number of chromites from other parageneses incorrectly assigned to the DI field. Only $0.4 \%$ and $0.3 \%$ of basaltic and groundmass kimberlite spinels, respectively, are assigned to the DI field. Significant overlap with the DI field exists for chromites from spinel peridotite xenoliths; $10 \%$ fall within the DI classification field.

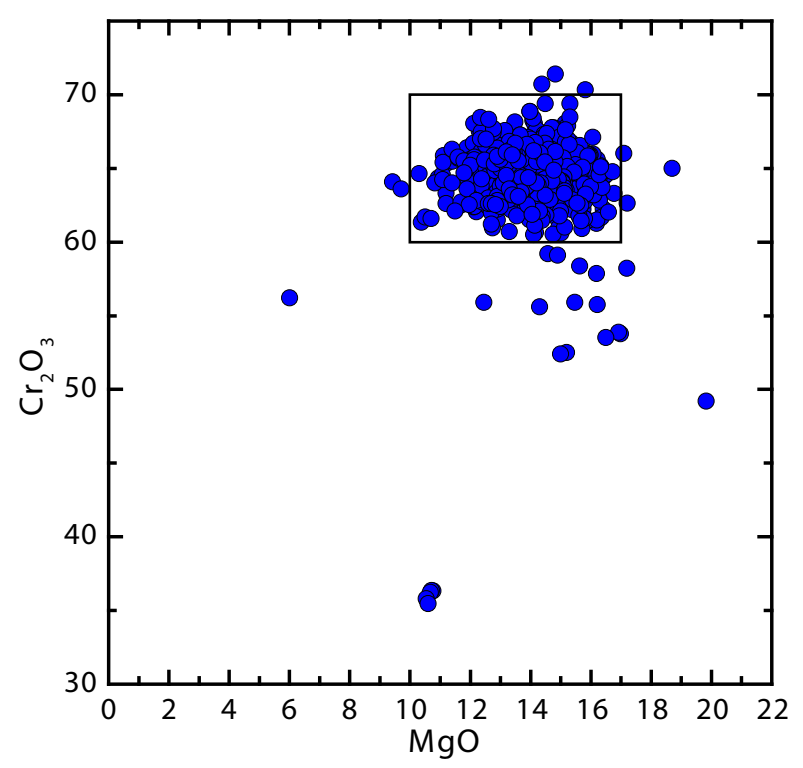

Figure 1: $\mathrm{Cr}_{2} \mathrm{O}_{3}$ vs. MgO of chromite inclusions in diamond $(\mathrm{n}=824)$ from worldwide locations updated from Fipke et al. (1995).

The remaining (i.e. non DI field) spinels are classified based on their co-variation in $\mathrm{TiO}_{2}$ and MgO. Spinels from mafic bulk compositions have high $\mathrm{TiO}_{2}$ concentrations at low $\mathrm{MgO}$ and decrease in $\mathrm{TiO}_{2}$ with increasing $\mathrm{MgO}$ defining a compositional trend bounded at the upper $\mathrm{TiO}_{2}$ limit by an exponential 
decay curve (Figure 2). Thus, a "basaltic" field may be defined as the region below the bounding curve. Chromites from spinel facies peridotite xenoliths have compositions that plot within the MgO-rich portion of the basaltic field. We have defined a cut-off between basaltic and ultramafic compositions at $12.7 \mathrm{wt} \%$ $\mathrm{MgO}$, based on the mean MgO concentration of peridotitic chromites minus one standard deviation. Thus, the ultramafic field includes $84 \%$ of the peridotitic samples in our database. Some overlap between the "basaltic" and ultramafic fields is implicit in this definition.

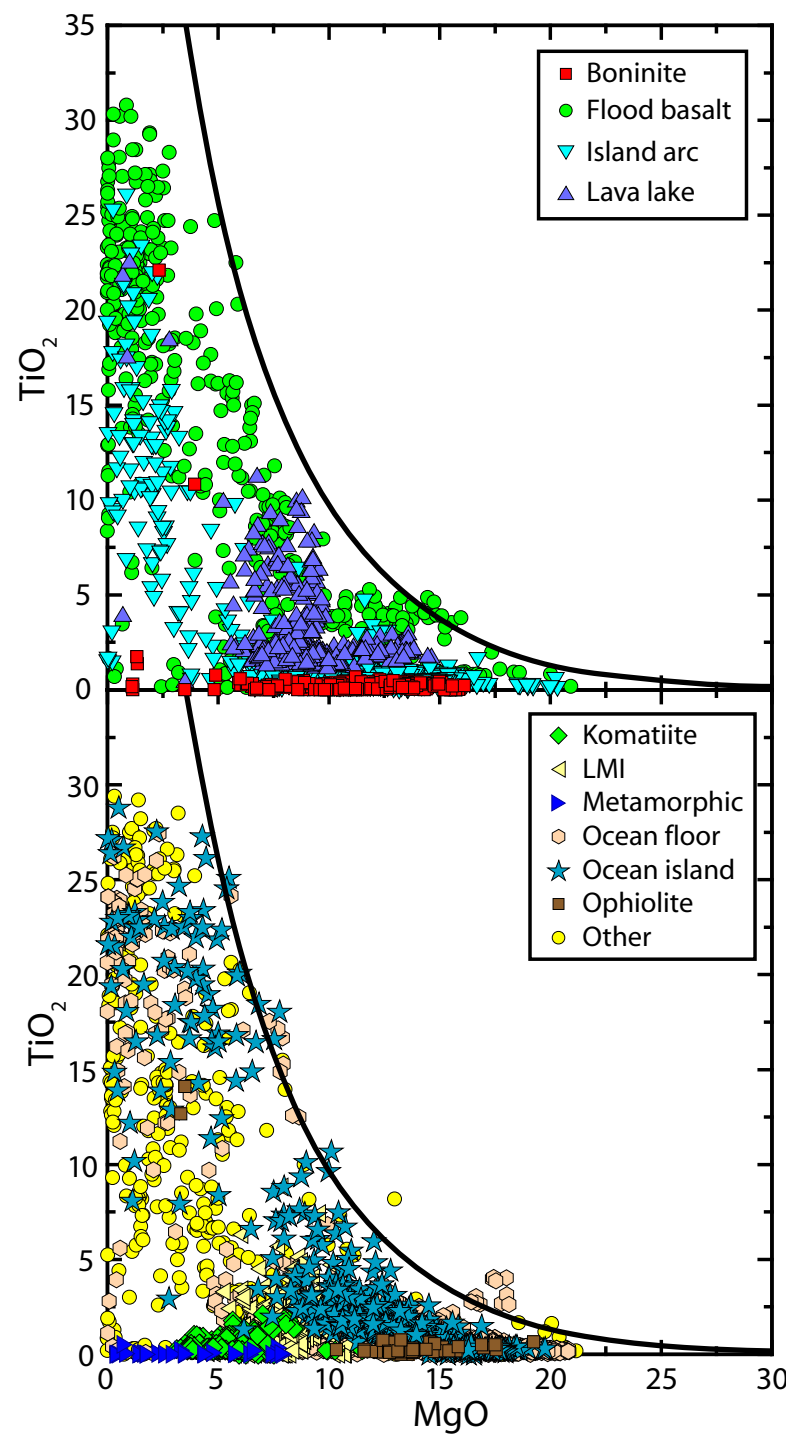

Figure 2: $\mathrm{MgO}^{-\mathrm{TiO}_{2}}$ co-variation of chromites $(\mathrm{n}=6085)$ from a variety of mafic rocks. The upper limit in $\mathrm{TiO}_{2}$ concentration of "basaltic" spinels is fit with an exponential decay curve defined by the equation: $\mathrm{TiO}_{2}=71.034 \times e^{(-0.2 \times \mathrm{MgO})}$

Groundmass spinels from Group 1 kimberlites have a unique compositional trend originating from magnesian-aluminous-chromite towards magnesianulvöspinel corresponding to Trend 1 of Mitchell (1986). This Ti-enrichment trend in magnesian groundmass spinels from Group 1 kimberlites results in a positive correlation between $\mathrm{TiO}_{2}$ and $\mathrm{MgO}$ unique among all spinel source rocks (Figure 3). Groundmass spinels of lamprophyres (lamproites, minettes etc.) and Group 2 kimberlites have Ti-enrichment occurring at low MgO concentration and consequently they plot within the basalt field.

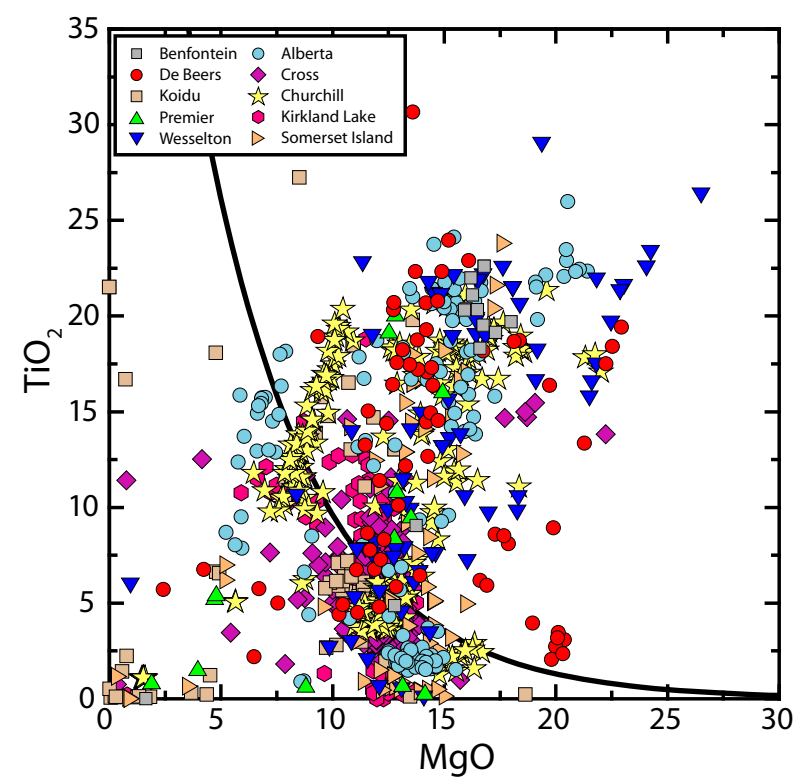

Figure 3: Kimberlite groundmass spinels $(n=1322)$ plotted on the same $\mathrm{MgO}-\mathrm{TiO}_{2}$ diagram as Figure 2. The unique compositional trend of Group 1 kimberlite spinels is evident in the concurrent enrichment of $\mathrm{MgO}$ and $\mathrm{TiO}_{2}$.

The three classification fields based on $\mathrm{TiO}_{2}$ vs. MgO are shown in Figure 4.

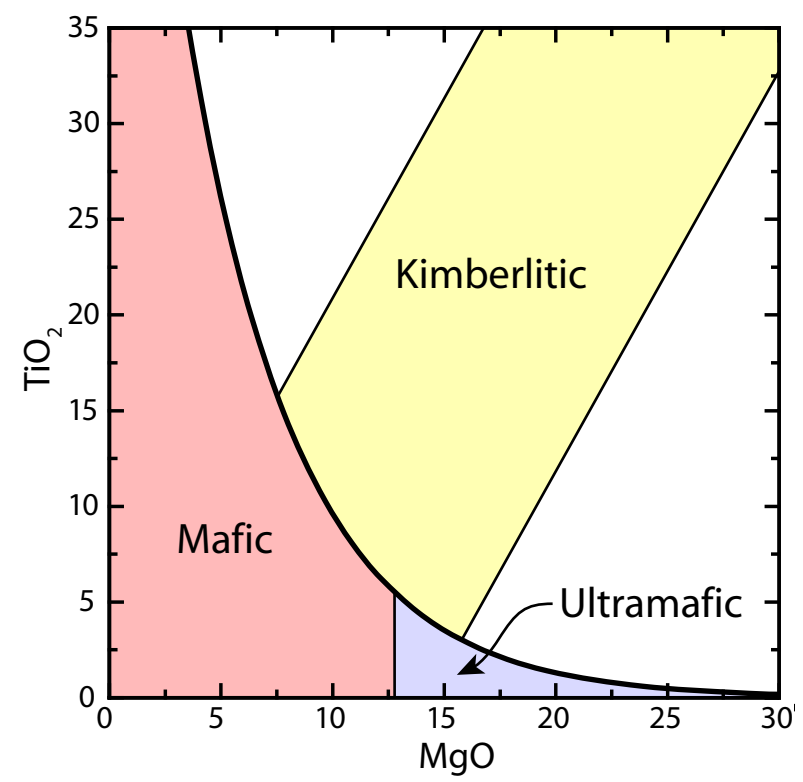

Figure 4: Summary of the classification scheme based on $\mathrm{MgO}-\mathrm{TiO}_{2}$ concentrations of chromites.

\section{Application}

This classification scheme can be applied to diamond exploration in two ways. Firstly, as already common practice during kimberlite exploration (c.f. Fipke et al. 1995), the identification of chromite grains derived 
from highly depleted and deep seated ultramafic sources in till and sediment samples with compositions extending into the field of DI chromites may be used as an indication of high diamond potential.

Secondly, spinels may be used to positively identify kimberlite as the source rock. Because of their small size (typically $<100 \mu \mathrm{m}$ ) and magnetic characteristics, kimberlite groundmass spinels usually are only a minor component in recovered dense media concentrates. This limitation is, however, mitigated by the uniqueness of kimberlite spinel compositions: only a few spinels plotting within the kimberlite groundmass field are sufficient to positively identify Group 1 kimberlite as a regional chromite source. Positive identification of kimberlite can be accomplished by analyzing as few as $\sim 30$ groundmass spinels. This second application, positive identification of Group 1 kimberlite, extends to classification of volcanic rock samples occurring in outcrop or as float.

\section{References}

Barnes SJ, Roeder PL (2001) The range of spinel compositions in terrestrial mafic and ultramafic rocks. $\mathrm{J}$ Petrol 42:2279-2302

Fipke CE, Gurney JJ, Moore JJ (1995) Diamond exploration techniques emphasising indicator mineral geochemistry and Canadian examples, vol 423. 86 pp.

Griffin W, Ryan C (1995) Trace elements in indicator minerals: area selection and target evaluation in diamond exploration. J Geochem Explor 53:311-337

Griffin WL, Fisher NI, Friedman JH, Ryan CG (1997) Statistical techniques for the classification of chromites in diamond exploration samples. J Geochem Explor 59:233-249

Griffin WL, Ryan CG, Gurney JJ, Sobolev NV, Win TT (1994) Chromite macrocrysts in kimberlites and lamproites: geochemistry and origin. In: Meyers HOA, Leonardos $\mathrm{OH}$ (eds) Proceedings of the $5^{\text {th }}$ International Kimberlite Conference, vol 1. Companhia de Pesquisa de Recursos Minerais, pp 366-377

Lee DC, Madden J, Griffin BJ (2003) The importance of chromite morphology in diamond exploration. Extended Abstracts of the $7^{\text {th }}$ International Kimberlite Conference

Mitchell RH (1986) Kimberlites: Mineralogy, geochemistry, and petrology. Plenum Press, New York. 434 pp. 